\section{Seriously, Should We Be Treating Severe ARDS With High-Flow Nasal Cannula Oxygen?}

\section{To the Editor:}

We have read with interest the RESPIRATORY CARE article entitled "Use of high-flow nasal cannula oxygen therapy in subjects with ARDS: a 1-year observational study". ${ }^{1}$ We are surprised that, compared with an overall mortality of $29 \%$, the mortality in the group treated with high-flow nasal cannula (HFNC) oxygen therapy and subsequently needing intubation was $50 \%$. This is close to the value determined by Antonelli et $\mathrm{al}^{2}$ in 2007: $56 \%$ mortality in subjects treated with noninvasive ventilation (NIV) and finally intubated due to NIV failure. Because there was a possible delay in the intubation of these subjects the result was a higher mortality rate. In addition, mortality could have been prevented if, instead of being treated with NIV, patients with ARDS were initially intubated and treated with the open-lung strategy with high PEEP. ${ }^{3}$

The current mortality due to ARDS varies between 20 and $60 \%$ depending on many factors, but there is a clear relationship that has been established between the level of PEEP, the $\mathrm{P}_{\mathrm{aO}_{2}} / \mathrm{F}_{\mathrm{IO}_{2}}$ that is reached with this PEEP, and mortality. ${ }^{4}$ Thus, in patients intubated and ventilated with a PEEP of $>10 \mathrm{~cm} \mathrm{H} \mathrm{H}_{2} \mathrm{O}$, if the $\mathrm{P}_{\mathrm{aO}_{2}} / \mathrm{F}_{\mathrm{IO}_{2}}$ is $<150$, the mortality rate is $60.3 \%$, which is very similar to the rate found by Antonelli et $\mathrm{al}^{2}$ in subjects with delayed intubation.

In ARDS, the ventilation strategy is aimed at reducing the intrapulmonary shunt with the use of continuous distending pressure. Due to the high rate of associated failure and secondary mortality, there are some physicians who advise against the continuation of NIV in patients with ARDS if, after $1 \mathrm{~h}$ of treatment, oxygenation has not improved to a $\mathrm{P}_{\mathrm{aO}_{2}} / \mathrm{F}_{\mathrm{IO}_{2}}$ of $>175^{2}$ (the intrapulmonary shunt when $\mathrm{P}_{\mathrm{aO}_{2}} / \mathrm{F}_{\mathrm{IO}_{2}}>175$ is $\sim 35 \% 5$ ). In recent clinical trials involving hypoxemic respiratory failure in the pediatric population, HFNC was not shown to have better results than standard low-flow oxygen therapy, ${ }^{6}$ and both therapies had a higher mortality rate than CPAP therapy. ${ }^{7}$

In mild hypoxemic situations, although NIV produces better oxygenation, HFNC is subjectively better tolerated, and it can be considered as a reasonable alternative ther- apy. ${ }^{8}$ However, we disagree with the use of HFNC in moderate or severe ARDS $\left(\mathrm{P}_{\mathrm{aO}_{2}} /\right.$ $\mathrm{F}_{\mathrm{IO}_{2}}$ of $<200$ ). ARDS is a clinical condition with high mortality. If the decision to use NIV is made, it should be started with CPAP or bi-level positive airway pressure. However, if an improvement in oxygenation $\left(\mathrm{P}_{\mathrm{aO}_{2}} / \mathrm{F}_{\mathrm{IO}_{2}}\right.$ of $\left.>175\right)$ is not obtained after $1 \mathrm{~h}$ of NIV, the patient should be intubated to improve the level of recruitment and to minimize the intrapulmonary shunt.

So the question now is, are we sure that using HFNC initially, instead of conventional mechanical ventilation in patients with severe ARDS, does not increase mortality? In our opinion, the answer is no. If, as patients, we happened to have severe ARDS, we would definitely choose conventional mechanical ventilation from the very beginning.

Alberto Medina MD PhD

Pediatric Intensive Care Unit Department of Pediatrics

Hospital Universitario Central de Asturias Oviedo, Asturias, Spain

Vicent Modesto i Alapont MD PhD Pediatric Intensive Care Unit Department of Pediatrics

Hospital Universitari i Politècnic La Fe València, Valencia, Spain

The authors have disclosed no conflicts of interest.

DOI: $10.4187 /$ respcare. 04147

\section{REFERENCES}

1. Messika J, Ben Ahmed K, Gaudry S, Miguel-Montanes R, Rafat C, Sztrymf B, et al. Use of high-flow nasal cannula oxygen therapy in subjects with ARDS: a 1-year observational study. Respir Care 2015; 60(2):162-169.

2. Antonelli M, Conti G, Esquinas A, Montini L, Maggiore SM, Bello G, et al. A multiple-center survey on the use in clinical practice of noninvasive ventilation as a firstline intervention for acute respiratory distress syndrome. Crit Care Med 2007; 35(1):18-25.

3. Amato MB, Barbas CS, Medeiros DM, Magaldi RB, Schettino GP, Lorenzi-Filho $\mathrm{G}$, et al. Effect of a protective-ventilation strategy on mortality in the acute respiratory distress syndrome. N Engl J Med 1998; 338(6):347-354

4. Villar J, Fernández RL, Ambrós A, Parra L, Blanco J, Domínguez-Berrot AM, et al. A clinical classification of the acute respiratory distress syndrome for predicting out- come and guiding medical therapy. Crit Care Med 2015;43(2):346-353.

5. Reske AW, Costa EL, Reske AP, Rau A, Borges JB, Beraldo MA, et al. Bedside estimation of nonaerated lung tissue using blood gas analysis. Crit Care Med 2013; 41(3):732-743

6. Hathorn C, Ernst G, Hasan S, Wong D, Seear M. The Hi-flo study: a prospective open randomised controlled trial of high flow nasal cannula oxygen therapy against standard care in bronchiolitis (abstract) Thorax 2014;69:A38.

7. Chisti MJ. Respiratory support for children with severe pneumonia and hypoxaemia in a developing country: a randomized trial of bubble CPAP, high flow nasal cannula therapy and standard flow oxygen. $\mathrm{PhD}$ thesis, 2014. http://hdl.handle.net/11343/42117. Accessed May 5, 2014.

8. Schwabbauer N, Berg B, Blumenstock G, Haap M, Hetzel J, Riessen R. Nasal highflow oxygen therapy in patients with hypoxic respiratory failure: effect on functional and subjective respiratory parameters compared to conventional oxygen therapy and non-invasive ventilation (NIV). BMC Anesthesiol 2014;14:66

\section{Seriously, Should We Be Treating Severe ARDS With High-Flow Nasal Cannula Oxygen?-Reply}

In Reply:

We thank Drs Medina-Villanueva and Modesto i Alapont for their interest in our work. ${ }^{1}$ They question the use of high-flow nasal cannula (HFNC) oxygen for the management of ARDS. The crucial point missed by Drs Medina-Villanueva and Modesto i Alapont is the basic philosophy of acute respiratory failure management.

We know that not all patients who are ultimately diagnosed with ARDS immediately fulfill all ARDS criteria. In addition, not all patients with ARDS arrive already intubated in the ICU, and not all of them present with immediate intubation criteria. This means that a significant proportion of patients arrive in the ICU with severe acute respiratory failure, still breathing spontaneously, usually with supplemental oxygen administered via a face mask. Hence, until recently, clinicians could choose from 3 options: immediately intubate (even in the absence of intubation criteria as suggested by Drs MedinaVillanueva and Modesto i Alapont), initiate noninvasive ventilation (NIV), or continue conventional oxygenation. 
We contend that there is now a fourth option, which is the use of HFNC. There is ample evidence that HFNC performs better than a conventional face mask in these subjects. ${ }^{2-4}$ There are now convincing data demonstrating that HFNC performs better than NIV 5 and that a certain degree of ventilator-induced lung injury may occur with NIV. ${ }^{6}$ Thus, the initial management of ARDS in the ICU, before intubation, should preferably be done with HFNC.

Drs Medina-Villanueva and Modesto i Alapont further imply that our mortality rate is high and cite the study by Amato et al ${ }^{7}$ and the so-called benefit of their open-lung strategy. A more serious interpretation of the study by Amato et al is that their observed difference in mortality was the result of an excessive mortality in the control group and not a reduction obtained with the open-lung strategy. ${ }^{8}$

The risk of unduly delaying intubation and increasing mortality in patients subsequently intubated as observed with NIV in de novo acute respiratory failure is a legitimate concern. ${ }^{9}$ However, a more serious analysis of our study and a better knowledge of the literature indicate that this situation may not have been encountered in our study. Mean durations of NIV associated with excess mortality due to delayed intubation exceeded $75 \mathrm{~h} !^{10}$ In one study, ${ }^{10}$ NIV duration in subjects who ultimately required intubation was considerably longer in subjects who died than in those who survived (78 vs $32 \mathrm{~h}$ ). Our figures are totally opposite: not only was our median duration of HFNC in the case of failure much shorter $(20 \mathrm{~h})$ than reported with NIV, but importantly, it was shorter in subjects who failed than in those who succeeded with HFNC (20 vs 32 h). Finally, HFNC duration in subjects who required intubation was identical in those who ultimately died and those who survived. Thus, we contend that our subjects were intubated in a timely fashion when intubation criteria were met.

An additional benefit of HFNC is the use of a single device to manage patients in acute respiratory failure, from ICU admission up to intubation, where recent data suggest that pre-oxygenation is improved with HFNC. ${ }^{11}$ Cogent analysis and interpretation of medical literature are difficult skills and a serious matter.

Jean-Damien Ricard MD PhD Jonathan Messika MD Didier Dreyfuss MD

Institut National de la Santé et de la Recherche Médicale

Infection, Antimicrobials, Modelling,

Evolution

Unité Mixte de Recherche 1137

Université Paris Diderot

IAME

UMR 1137

Sorbonne Paris Cité Paris, France

and

Assistance Publique-Hôpitaux de Paris Service de Réanimation

Médico-chirurgicale

Hôpital Louis Mourier

Colombes, France

Karim Ben Ahmed MD

Romain Miguel-Montanes MD

Assistance Publique-Hôpitaux de Paris

Service de Réanimation

Médico-chirurgicale

Hôpital Louis Mourier

Colombes, France

Stéphane Gaudry MD

Assistance Publique-Hôpitaux de Paris

Service de Réanimation

Médico-chirurgicale

Hôpital Louis Mourier

Colombes, France

Université Paris Diderot

Sorbonne Paris Cité

ECEVE

UMR 1123

Paris, France

David Hajage MD

Université Univ Paris Diderot

Sorbonne Paris Cité

ECEVE

UMR 1123

Paris, France

Dr Ricard has disclosed relationships with Fisher \& Paykel Healthcare and Covidien. Dr Messika has disclosed a relationship with Basilea Pharmaceutica. The other authors have disclosed no conflicts of interest.

DOI: $10.4187 /$ respcare. 04314

\section{REFERENCES}

1. Messika J, Ben Ahmed K, Gaudry S, MiguelMontanes R, Rafat C, Sztrymf B, et al. Use of high-flow nasal cannula oxygen therapy in subjects with ARDS: a 1-year observational study. Respir Care 2015;60(2):162-169.

2. Sztrymf B, Messika J, Bertrand F, Hurel D, Leon R, Dreyfuss D, Ricard JD. Beneficial effects of humidified high flow nasal oxygen in critical care patients: a prospective pilot study. Intensive Care Med 2011;37(11):1780-1786.

3. Sztrymf B, Messika J, Mayot T, Lenglet H, Dreyfuss D, Ricard JD. Impact of high-flow nasal cannula oxygen therapy on intensive care unit patients with acute respiratory failure: a prospective observational study. J Crit Care 2012;27(3):324.e9-324.e13.

4. Roca O, Riera J, Torres F, Masclans JR. Highflow oxygen therapy in acute respiratory failure. Respir Care 2010;55(4):408-413.

5. Frat JP, Thille AW, Mercat A, Girault C, Ragot S, Perbet S, et al. High-flow oxygen through nasal cannula in acute hypoxemic respiratory failure. N Engl J Med 2015; 372(23):2185-2196.

6. Carteaux G, Millán-Guilarte T, De Prost N, Razazi K, Thille AW, Schortgen F, et al. High tidal volume is associated with NIV failure in acute hypoxemic respiratory failure. Intensive Care Med 2014;40(Suppl 1):O234.

7. Amato MB, Barbas CS, Medeiros DM, Magaldi RB, Schettino GP, Lorenzi-Filho $\mathrm{G}$, et al. Effect of a protective-ventilation strategy on mortality in the acute respiratory distress syndrome. $\mathrm{N}$ Engl J Med 1998;338(6):347-354.

8. Parshuram C, Kavanagh B. Meta-analysis of tidal volumes in ARDS. Am J Respir Crit Care Med 2003;167(5):798; author reply 798-800.

9. Ricard JD, Messika J, Sztrymf B, Gaudry S. Impact on outcome of delayed intubation with high-flow nasal cannula oxygen: is the device solely responsible? Intensive Care Med 2015 [Epub ahead of print]. doi: 10.1007/s00134-0153766-5.

10. Carrillo A, Gonzalez-Diaz G, Ferrer M, Martinez-Quintana ME, Lopez-Martinez A, Llamas N, et al. Non-invasive ventilation in community-acquired pneumonia and severe acute respiratory failure. Intensive care medicine 2012;38(3):458466.

11. Miguel-Montanes R, Hajage D, Messika J, Gaudry S, Bertrand F, Rafat C, et al. Use of high-flow nasal cannula oxygen therapy to prevent desaturation during tracheal intubation of intensive care patients with mild-to-moderate hypoxemia. Crit Care Med 2015;43(3):574-583. 